\title{
The Effect of Federal Government Revenue and Expenditure On Economic Growth in Nigeria - An Empirical Review
}

\begin{abstract}
${ }^{1}$ Ayoka Cynthia Odinakachi, ${ }^{2}$ Nzotta Samuel Mbadike and ${ }^{3}$ Kanu Success Ikechi
1,2 Department of Management Technology (FMT), School of Management Technology, Federal University of Technology, Owerri (FUTO) P.M.B 1526, Owerri,, Imo State, Nigeria.

${ }^{3}$ Department of Banking and Finance, Faculty of Social and Management Sciences, K.O. Mbadiwe University (KOMU), Ogboko Ideato, P.M.B 6, Orlu Imo State, Nigeria. Abstract: This study examined the effect of federal government revenue and expenditure on the economic growth of Nigeria for the period 1983 to 2018. Prior to now many studies have been completed on the subject matter and yet there doesn't seem to be a consensus of opinion amongst the different researchers on the relationship between revenue and expenditure interface in Nigeria. This could be ascribed to the different approaches gies set forward to clarify the relationship; thus warranting the need for this research. The investigation embraced an ex-post facto research design to produce test results via Bounds test, ARDL short/long run estimates and to make forecasts. The full scale economic factors used in the study includes Real Gross domestic product (proxy for economic growth), federal government retained revenue, non-oil revenue, capital expenditure and recurrent expenditure. We chose to be different in this study with a conscious omission of oil revenue as a variable of study. Findings of the research showed that federal government retained revenue; non-oil revenue and recurrent expenditure were statistically significant in explaining the relationship with economic growth in the short run; while capital expenditure was not at $5 \%$ Alpha level. Federal government retained revenue was also found to be statistically significant in the long run. On the basis of these findings, it was concluded that the influential growth variables are federal government retained revenue; non-oil revenue and recurrent expenditure. The researchers thus recommend that government should be tactful in her efforts at fiscal policy synchronization. There is need to monitor Nigeria's expenditure pattern, increase in revenue and a consequent increase in governments retained revenue. This will make for an effective adjustment in the utilization of capital expenditures and to assist with raising the level of economic growth in Nigeria.
\end{abstract}

Keywords: Federal Government Retained Revenue, Non-oil Revenue, Recurrent Expenditure, Capital Expenditure and Economic Growth

\section{Introduction}

\subsection{Background Information}

Fiscal policy is a macro-economic instrument employed by government to ensure stability in an economy. It engenders sustainable growth, price stability, full employment, and /maximum utilization of available resources. To achieve these lofty goals, policy makers are saddled with fiscal policy adjustments and implementations. This particularly applies to policy makers in developing economies where there is an urgent need for infrastructural investment.

However, the resources needed to make these expenses are grossly inadequate thereby limiting the imperatives of Harrod- Domar growth model prerequisite which explicitly points to the importance of greater levels of savings. In a developing economy like Nigeria, tax revenues are low due to the low income levels of her citizenry.

Fiscal policy (which is the use of revenue and expenditure framework adjustments to influence the level of economic activities in an economy) can be expansionary or restrictive. Its application 
Ayoka Cynthia Odinakachi, Nzotta Samuel Mbadike and Kanu Success Ikechi

The Effect of Federal Government Revenue and Expenditure On Economic Growth in Nigeria - An

Empirical Review

is based on the objectives, developmental strides and levels of a nation's economy. For instance, expansionary fiscal policy, which implies a reduction in tax rates and an increase in government expenditures, may lead to a budget deficit at the start, but in the long run can reinforce growth. This is in tandem with the Keynesian economic policy, which opines that a budget deficit can give rise to economic growth in the long run.

A necessary condition for the establishment of an effective fiscal policy is to understand and establish appropriate links between government revenue and expenditures. However, the link between the two is determined by nature of fiscal policy adopted by the government. The sources of government revenue vary from one country to another and changes with time, depending on dynamics of the economy (chase-Dun, 1975).

For example, Nigeria's revenue base was initially hinged on Agriculture (i.e. proceeds from the sale of cocoa rubber, cotton, palm trees, groundnut, cotton and timber) in the 1970s, but changed to oil and gas as a result of the prominence of oil in the Nigerian economy from the 80 s till date (Usman and Abdullahi, 2015). This has made the Nigeria economy vulnerable to commodities and price volatility over the years. In addition, the continuous decline in the prices of crude oil at the international market has eaten deeply into the financing and execution of fiscal budgets in Nigeria and has plunged the economy into recession in recent times (CBN, 2016). In 2013, the oil and gas constituted about 85 to 90 per cent of foreign exchange earnings in terms of revenue and about 75 per cent in terms of export. In recent times, this contribution has continued to decline to about 65 and 55 percent for foreign exchange earnings (CBN, 2015). The several attempts made by different governments in diversifying the Nigerian economy have been seen as mere gimmicks or political propaganda rather than calculated attempts at revamping / improving the economy and the lives of her citizenry.

Revenue generation has not only rewritten the economic history of Nigeria and her growth path but has attracted a myriad of curses such as environmental degradation, pipeline vandalism, oil theft and low standard of living with a high number of people living below the poverty line. Ironically, despite the resurgence in the price of crude oil after the setbacks occasioned by immediate past recession experienced in Nigeria, she has not been able to establish that all -important link between its revenue and expenditure pattern overtime to ensure sustainable growth.

Perhaps, another interesting aspect of public finance that has received much attention in literature, debate and empirical analysis is the effect of public expenditures. Many supports a large public expenditure on the grounds that it pulls money into circulation, increases investment, and reduces tax averseness. However, public expenditure has some obvious consequences. For instance, when the state enters the market for factor inputs or labor in the factor market, it stimulates unhealthy competition with the private sector firms for these same materials or labor services. As such, the government becomes the largest purchaser of goods and services because of its widespread activities as hitherto evidenced in Nigeria. For decades, public expenditures have been expanding in Nigeria, as in any other country of the world.

Akpan (2005) believes that the noticed growth in broad daylight spending seems to apply to most nations paying little attention to their degree of economic turn of events. This requires the need to decide if the conduct of Nigerian public expenditure and the economy depends on the Wagner's (1883) law of Ever-expanding state movement or the Keynesian (1936) theory and Friedman's (1978) or the peacock and Wiseman's (1979) hypotheses .

From the foregoing analysis, it could be said that the size of government expenditure and revenue are two sides of the same coin in fiscal management, which is peculiar to all nations of the world. This goes to explain the importance of the two variables in determining the direction of economic growth. Thus, the main objective of this study is to empirically ascertain the relationship between government's expenditure and revenue pattern in Nigeria over the period 1983 to 2018.

\subsection{Problem Statement}

It is the craving of each country to achieve rapid economic growth and development. Funds are needed to this effect as development entails spending. The expenses incurred will provide the necessary infrastructures such as health care, educational and social security services etc. Funds 
Ayoka Cynthia Odinakachi, Nzotta Samuel Mbadike and Kanu Success Ikechi

The Effect of Federal Government Revenue and Expenditure On Economic Growth in Nigeria - An

Empirical Review

spent on the provision of infrastructures are basically sourced from taxes, fines, royalties, borrowings and grants from the states, national and international governments. This goes to justify the assertion that valid and significant monetary development and advancement can't be accomplished without fiscal management

According to the Keynesian perspective, government's association in the undertakings of a state can trigger off economic growth by encouraging deficit financing and expenditure in the face of a decrease in government revenue and an increase in government expenditure as supported by Wager's hypothesis of increasing expenditure of the state. Due to the intrigues surrounding this subject matter, different scholars have come up with 4 alternative hypotheses to explain this phenomenon and to provide an explanation for fiscal management but they have only succeeded in creating variations as a means to the end (Kanu, Ozurumba and Ihemeje; 2014). First is the revenue-spend hypothesis of Friedman (1978) which assumes that changes in state revenue leads to changes in government expenditure by almost the same proportion, but in the same direction.

Second is the spend-income speculation which expects that adjustments of expenditure can prompt changes in pay as evolved by Peacock and Wiseman (1979). As per this speculation, emergency in an economy could prompt a removal impact i.e., the current expansion in government spending prompts an increment in income. This kind of causality associates income with consumption

Meltzer and Richard (1981) described yet another causality relationship - the fiscal synchronization hypothesis which Posits that government determines its expenditures and revenues simultaneously based on the cost benefit analysis of the planned government programs. The last but not the least is the institutional separation hypothesis that is of an opposite view with the fiscal synchronization hypothesis. It posits that government determines its expenditures and revenues independently

From the foregoing analyses, it is evident that empirical studies on the relationship between government revenues and expenditures appears to be inconsistent with one another. This goes to underscore the importance of the variables- revenues and expenditures in determining the economic growth path and nature of causality relationship between them. This study seeks to add her voice to the seeming disagreement between researchers on the effect of government revenue and expenditure on economic growth. We intend to ascertain what is prevalent in the Nigerian economic scene. That is the problem of study!

\subsection{Objectives of the Study}

The primary objective of this study is to determine the effect of federal government revenue and expenditure on economic growth of Nigeria. The specific objectives are to determine the impact of:

a) Non-oil revenue on economic growth in Nigeria;

b) Federal government retained revenue on economic growth in Nigeria;

c) Recurrent expenditure on economic growth in Nigeria.

d) Capital expenditure on economic growth in Nigeria.

e) The explanatory variables on economic growth in Nigeria.

\subsection{Research Questions}

The following research questions were detailed for this investigation.

i) To what extent has non-oil revenue impacted on economic growth in Nigeria;

ii) To what extent has retained revenue impacted on economic growth in Nigeria;

iii) To what extent has recurrent expenditure impacted on economic growth in Nigeria;

iv) To what extent has capital expenditure impacted on economic growth in Nigeria; and lastly

iv) Is there a joint relationship between the explanatory variables and economic growth in Nigeria?

\subsection{Hypotheses of Study}

The following hypotheses are formulated for this investigation. 
Ayoka Cynthia Odinakachi, Nzotta Samuel Mbadike and Kanu Success Ikechi

The Effect of Federal Government Revenue and Expenditure On Economic Growth in Nigeria - An

Empirical Review

H01: There is no significant relationship between non-oil revenue and the economic growth of Nigeria.

H02: There is no significant relationship between federal governments retained revenue and the economic growth of Nigeria.

H03: There is no significant relationship between recurrent expenditure and economic growth of Nigeria.

H04: There is no significant relationship between capital expenditure and economic growth of Nigeria.

H05: There is no significant joint relationship between the explanatory variables and economic growth of Nigeria.

\subsection{Significance of the Study}

The study will provide an insight to policymakers, researchers and to the general public .It could assist them in making informed decisions on the relationships between revenue and expenditure interactions in the long. The study will also serve as reference material for future and further works in the area of government revenue, expenditure and economic growth path in Nigeria and in other sovereign nations.

\subsection{Scope of the Study}

The scope of study centers on the effect of federal government revenue and expenditure on economic growth in Nigeria. It lays emphasis on the non-oil revenue and actual public expenditure aggregates. The period 1983-2018 was chosen as it is considered long enough to ascertain long run effects of federal government revenue and expenditure on economic growth in Nigeria.

\section{Literature Review}

\subsection{Conceptual Framework}

Conceptual framework of this study is based on the following variables.

- Public Revenue

- The concept of government revenue.

- Sources of government revenue

- Problems of revenue generation by the state and local government

- Classification of public expenditure

- The role of public expenditure.

- The concept of economic growth

- Public expenditure and economic growth.

These are briefly discussed below:

\subsubsection{Public Revenue}

Public expenditure can be characterized as the expenditure incurred by government like the federal, state, and local governments to satisfy the aggregate needs of individuals. It is fundamentally made by the government of a country on citizen's needs and items such as pension, provision of infrastructure etc. Bhatia (2008) defines Public expenditure as the expenses which a government incurs for (i) its own maintenance, (ii) the society and the economy, and (iii) helping other countries. Public expenditure refers broadly to expenditure made by local, state, and national government agencies as distinct from those of private individuals. Public Expenditure also comprises of government payments for the goods and services acquired and for the works done pursuant to their respective laws, social security contributions, interest payments of domestic and foreign debts, general borrowing expenditures, payments resulting from the discounted sale of borrowing instruments, economic, financial, and social transfers, donations and grants, and others.

\subsubsection{The concept of Government Revenue}

Section 162 (10) of Nigeria's 1999 constitution, defines revenue as any income returns accruing from or derived by the government from any receipt arising from the operation or any law, 
Ayoka Cynthia Odinakachi, Nzotta Samuel Mbadike and Kanu Success Ikechi

The Effect of Federal Government Revenue and Expenditure On Economic Growth in Nigeria - An

Empirical Review

property held by the government and any returns by way of interest or loans and individuals in respect of shares or interest held by the government in any company or statutory body

Government revenue includes all amounts of money (i.e., taxes and fees) received from sources outside the government entity. Large governments usually have an agency or department responsible for the collection of government revenue from companies and individuals.

Government revenue may also include reserve bank currency, which is printed, and this is recorded as an advance to the retail bank together with a corresponding currency in circulation. The income is derived from the official cash rate for instruments such as 90 days bills.

\subsubsection{Sources of Government Revenue}

Prior to the oil boom of early 1970s, agriculture was the mainstay of the economy as the sectors contribution to GDP was about $70 \%$. This contribution has fallen to about $30 \%$ with the advent of crude oil. Since the advent of crude oil, the trend has changed in favor of the latter, now it is the oil revenue that contributes the bulk of the federal government's revenue.

The main sources of revenue to the Nigeria government are largely grouped as oil and non oil revenues.

\subsubsection{Problems of Revenue Generation by the State and Local Government} Areas

There are many problems militating against the revenue generation of the state and local government areas in Nigeria. These problems include over-dependence on statutory allocation from the federal government (federation account), lack of competent and honest manpower and inadequate mobility and infrastructural facilities. Others are tax evasion, political interference, problem of byelaws and lack of clear act jurisdiction, Lack of enlightenment programs, high rate of illiteracy and low standards of living.

\subsubsection{Classification of Public Expenditure}

First, public expenditure can be classified in terms of the kind of goods and services bought. Second, it can be classified according to the official body and organization from which the budget

is paid. For example the federal government and its ministries; state and local government areas authorities; Separate public bodies and international organizations. Third, public expenditure can be classified according to the macro-function at which it is directed:

\subsubsection{The Role of Public Expenditure}

Public expenditure plays four main roles:

I) It adds to current effective demand.

ii) It communicates a planned drive on the economy, which can be utilized for adjustment, business cycle reversal and development purposes;

iii) It builds the public enrichment of products for everyone and;

iv) It brings about certain externalities to the economy and society more so through its capital component. With its prioritized structure and its peculiar decision-making process, it substantiates the prevailing kind of state.

On the flip side of this study is the concept of economic growth. It behooves of us to chip in a word or two on it.

\subsubsection{The Concept of Economic Growth}

Economic growth can be defined as the steady process by which the productive capacity of the economy is increased over time to achieve rising degrees of public yield and pay (Todaro and Smith, 2005). In any case, it is appropriate to take note of the fact that growth is concerned exclusively with quantitative and quantifiable qualities. An economy can grow yet may not develop. It is hard to envision monetary advancement without financial development. The two concepts contrast in idea; however they are now and again utilized conversely. Though they differ in concept, they are sometimes used interchangeably.

\subsubsection{Public Expenditure and Economic Growth}

As indicated by Dalton (1954), public expenditure will in general influence the degree of creation in three potential manners:

1. It gives different sorts of social and monetary offices animating the ability to work of individuals. Expanded limit infers expanded effectiveness and more prominent work. 
Ayoka Cynthia Odinakachi, Nzotta Samuel Mbadike and Kanu Success Ikechi

The Effect of Federal Government Revenue and Expenditure On Economic Growth in Nigeria - An

Empirical Review

2. It initiates the public's readiness to work and save. Thus, their pay and way of life rise.

3. It adjusts the economy by reallocating the pay asset from useless exercises to useful ones.

This results in increase in production. This effect varies between developed and developing countries

\subsection{Theoretical Review}

\section{Revenue Theory on fiscal policy}

This theory recommends that government raise finance and uses it to fund public speculations for the arrangement of public labor and products just as designated formative undertakings. Policy decisions are made by government which settles on how best to designate the gathered restricted income to alternative contending areas. In taking choices, compromises are normally made. This could be via public spending on actual framework and human resources, distributing of assets between defense spending and human capital investment and the portion of assets between open interest in both physical and human resources foundation and interest payments on accumulated debt .

\section{Musgrave Theory on Public Expenditure}

Musgrave's theory on public expenditure states that at low level of per capita income, interest for public administrations will in general be exceptionally low, this is so in light of the fact that the low pay is dedicated to fulfilling essential necessities and that when per capita income begins to transcend these levels of low pay, the interest of government in the provision of basic infrastructures like healthcare, education and transport begins to rise, subsequently driving government to increase use on them. Musgrave thought that at high levels of per capita income, typical of developed economics, the rate of public sector growth tends to fall as the more basic wants are being satisfied

\section{Wiseman - Peacock Hypothesis.}

This theory specifies that public expenditure doesn't increase in a smooth and continuous way, but in jerks or step-like design. At a point when social unsettling influence happens, the government and individuals review the income position and consent to the necessary changes to finance the increased expenditure. They are now prepared to endure a higher weight of assessment and thus, the overall degree of use and income goes up.

\section{Wagner's Law of Increasing State Activity.}

Wagner hypothesized a functional relationship between industrial-ization and the relative importance of public sector activity. His observations led to what is now called as Wagner's Law of Increasing State Activity.

\section{The Keynesian Theory of Expenditure}

Keynes sees public expenditure as an exogenous factor which can be used as a policy instruments to advance financial development. He suggested that public expenditure can contribute positively to monetary development. Henceforth, an expansion in the public expenditure is probably going to prompt an increment in business, productivity, and speculation through multiplier effects on aggregate demand.

\subsubsection{Theoretical Connections Between Government Revenue and Expenditure: A Causality Review}

Based on the numerous theoretical attitudes and empirical studies, four types of causality relationships exists between government revenue and expenditure profiles. Each of them has a corresponding policy implication. They are:

i) The tax and spend or revenue -spend hypothesis. It assumes that adjustments of state income could prompt changes in government consumption. Friedman (1978) fostered the theory expressing that when government's incomes are expanding, her consumption profile gets expanded. This positive causality implies that an increase in tax revenues leads to budget deficit. ii) The tax and spend or spend-revenue hypothesis. It assumes that adjustments of expenditure lead to changes in pay. According to this theory, emergency circumstances lead to an uprooting impact i.e., the current expansion in government spending prompts an increment in government income. The policy implication is to reduce state consumptions which would then diminish government incomes, and eventually, the spending deficiency 
Ayoka Cynthia Odinakachi, Nzotta Samuel Mbadike and Kanu Success Ikechi

The Effect of Federal Government Revenue and Expenditure On Economic Growth in Nigeria - An

Empirical Review

iii) Fiscal synchronization: This hypothesis assumes that there is a two-way connection government revenue and expenditure. As a result, the decisions on revenues and expenditures are made simultaneously. The feedback loop between the variables implies that they are interdependent, and an appropriate policy implication is to make decisions on both revenue and expenditure sides that are required to solve the problem of budget deficit.

iv) The institutional separation hypothesis: It states that there is no reliance between the choices on government expenditure and revenues. This theory is hinged on the fact that executive and legislative authorities are independent. The strategy suggestion is that spending deficiency is an after effect of higher expansion in government spending than in revenue generation

\subsection{Empirical Review}

This section will discuss some relatively new empirical studies on the impact of government expenditures on economic growth in Nigeria.

Oyinlola and Akinnibosun(2013) examined the relationship between public expenditure and economic growth in Nigeria during the period 1970-2009. The study used components of public expenditure such as recurrent expenditure, capital expenditure, administrative expenses, community and social service and transfer. The result also showed the presence of a cointegrating relationship between the variables in the system thus, recommending that a drawn out relationship exists between them.

Gukat (2015), examined the relationship between government expenditure on human capital and economic growth in Nigeria. Using the error correction mechanism, the study found that public expenditure on human resources fundamentally affects monetary development in Nigeria Other studies with similar findings include Ohwofasa, Obeh, andAtumah (2012) and Chude and Chude (2013).

Kanu, ozurumba and Ihemeje (2014) examined the relationship between federal government of Nigeria's revenue and expenditure profile for the period 1970 to 2011 . Result of study showed a mixed bag scenario. First, there is a significant unidirectional causal movement from expenditures to revenues for 4 of the 8 revenue-expenditure pairs. This represents an average level of adherence to the Spend -Revenue hypothesis. Second, a significant bidirectional causal effect exists between 4 of the 8 receipt -expenditure pairs. This also indicates that Revenue Expenditure relationship at the federal level of government in Nigeria finds prevalence in the fiscal synchronization hypothesis.

Emori, Duke and Nneji (2015) researched the effect of government use on the Nigerian economy utilizing ADF unit root test and OLS regression test. They tracked down that public expenditure had a significant effect on the Nigerian economy.

Udoffia and Godson (2016) investigated the impact of federal government expenditure on the Nigerian economy using the OLS estimation technique and found that federal government capital and recurrent expenditure have a positive effect on real GDP.

Echekoba and Amakor (2017) using ordinary least squares technique examined the Impact Of Government Expenditure On Nigeria Economic Growth: They utilized Gross Domestic Product (a proxy for economic growth as the dependent variable) and Defense Expenditure, General Administration, Education expenditures and Health expenditures as explanatory variables found Expenditure on General Administration and Education to significantly impact on economic growth in Nigeria

Echekoba and Amakor (2017) using ordinary least squares technique examined the Impact Of Government Expenditure On Nigeria Economic Growth: They used Gross Domestic Product (a proxy for financial development as the dependant variable) and Defense Expenditure, General Administration, Education consumptions and Health uses as logical factors.They discovered that Expenditure on General Administration and Education to fundamentally affect on monetary development in Nigeria

\subsection{Gap in the Study}

A vast majority of past investigations focused on the oil sector as the predominant source of revenue. However, there is a shift of focus in our present study from the oil to the non-oil sector 
Ayoka Cynthia Odinakachi, Nzotta Samuel Mbadike and Kanu Success Ikechi

The Effect of Federal Government Revenue and Expenditure On Economic Growth in Nigeria - An

Empirical Review

and retained government revenue as key factors, while holding recurrent expenditure and capital expenditure aggregates for a robust model build. It is believed that aside from closing the gap in sample size and methodology, it will also close the gap in model specification.

\section{Methodology}

This study made use of an Ex-post facto research design. Secondary data was employed covering the period 1983-2018. The data were obtained from the Central Bank of Nigeria (CBN) Statistical Bulletin (2018) Edition.

\subsection{Model Specification.}

This study modeled economic growth as a function of government expenditure on health, general administration, education, and defense.

$\mathrm{RGDP}=\mathrm{f}(\mathrm{NON}-\mathrm{OIL}$ REV, RETREV, RECEXP, CAPEXP)

In econometric form:

RGDP $=b_{0}+b_{1}$ NON-OILREV $+b_{2}$ RETREV $+b_{3}$ RECEXP $+b_{4}$ CAPEXP $+e$

Where: $R G D P=$ Real gross domestic product.

NON-OILREV = Non-oil revenue.

FEDRETREV = Federal government retained revenue.

RECEXP $=$ Recurrent expenditure.

CAPEXP = Capital expenditure

$b_{1}-b_{4}$ are coefficients of parameters estimates and $b_{0}$ is the intercept of the model. $e$ is the white noise error term.

Apriori Expectations

It is expected that $b_{1}>0, b_{2}>0, b_{3}>0$ and $b_{4}>0$. The expected positive signs rest on the theoretical postulation that revenue and deficit spending (expenditure) as supported by Keynes through government involvement leads to economic growth. Our apriori expectations are briefly summarized in the table $x x$ below.

\begin{tabular}{|l|l|l|}
\hline Variable & Definition & Expected sign \\
\hline NON-OIL REV & Non-oil revenue & $(+)$ \\
\hline CAPEXP & Capital expenditure & $(+)$ \\
\hline RECEXP & Recurrent expenditure & $(+)$ \\
\hline FEDRETREV & Federal government retained revenue & $(+)$ \\
\hline
\end{tabular}

\section{Justification of the chosen variables}

Real gross domestic product: This is a macro-economic measure of the value of economic output adjusted for price changes. This adjustment transforms the nominal value measure i.e., nominal GDP into an index for quantity of total output.

Non-oil revenue: This is all revenue types not covered by oil-based resources. Basically, it comprises company income tax, customs and excise duties and value-added tax which constitute the most important sources of non-oil revenue in Nigeria.

Retained revenue: This is the revenue that is left after all government expenses have been deducted from the total revenue. It is the revenue that has been set aside by government for miscellaneous economic activities.

Recurrent expenditure: This refers to the cost of incurred expenses in an accounting year by the government or corporate firm. It is all payment other than for capital assets, including on goods and services, interest payments, subsidies, and transfers .In other words, it is the matching of costs and revenues of the accounting year.

Capital expenditure: This is the capital expense or money an organization or state sets aside to buy, maintain, or improve its fixed assets such as buildings, vehicles, equipment's, or land. Capital expenditure is a derived demand.

\subsection{Method of Data Analysis}

The Autoregressive Distributed Lag (ARDL) was used for the model estimation.

\subsection{Test of Significance}


Ayoka Cynthia Odinakachi, Nzotta Samuel Mbadike and Kanu Success Ikechi

The Effect of Federal Government Revenue and Expenditure On Economic Growth in Nigeria - An

Empirical Review

The variables were tested at $5 \%$ level of significance individually and jointly.

Decision rule: Accept $\mathrm{Ho}$ if $\mathrm{t}_{\mathrm{cal}}<\mathrm{t}_{\mathrm{tab}}$ at $\mathrm{a}=0.05$, otherwise reject $\mathrm{H}_{0}$. Alternatively, accept $\mathrm{Ho}$ if prob.value $>0.05$, otherwise, reject $\mathrm{H}_{\mathrm{o}}$.

\section{1: Data Analysis}

\section{Table 4.2.1: Lag length selection criteria.}

VAR Lag Order Selection Criteria

Endogenous variables: RGDP RECEXP CAPEXP NON-OILREV

FEDRETREV.

Included observations: 31

\begin{tabular}{lllllll}
\hline \hline Lag & LogL & LR & FPE & AIC & SC & HQ \\
\hline \hline 0 & -1189.841 & NA & $2.07 e+27$ & 77.08650 & 77.31779 & 77.16190 \\
& & & & & 71.98742 & \\
1 & -1064.295 & 202.4928 & $3.23 e+24$ & 70.59970 & $*$ & 71.05206 \\
& & 45.49779 & $1.91 e+24$ & 69.93771 & & 70.76705 \\
2 & -1029.034 & $*$ & $*$ & $*$ & 72.48188 & $*$ \\
\hline \hline
\end{tabular}

From the table above, the dominant lag length is 2 ; hence the lag of 2 will be used throughout the estimation and analysis.

Table 4.2.1B: Normality test

The normality test indicates that the probability value $(0.69484)$ is greater than 0.05 ; hence the sample data has satisfied the normality distribution assumption.

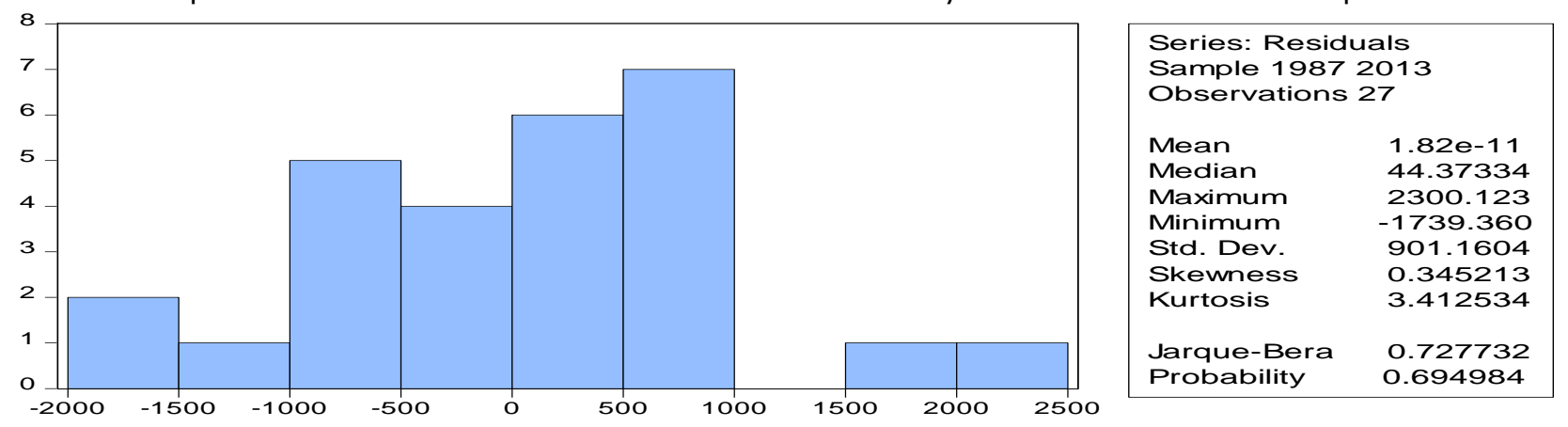

Source: E-views 10 Regression output

\section{Correlations}

\begin{tabular}{|l|l|l|l|l|l|}
\hline VARIABLES & CAPEXP & FEDRETREV & NON-OILREV & RECEXP & RGDP \\
\hline CAPEXP & 1 & 0.0885 & 0.0231 & 0.2875 & -0.0746 \\
\hline FEDRETREV & 0.0885 & 1 & 0.9366 & 0.8620 & 0.9620 \\
\hline NON-OIL REV & 0.0231 & 0.9366 & 1 & 0.8129 & 0.9653 \\
\hline RECEXP & 0.2875 & 0.8620 & 0.8129 & 1 & 0.8185 \\
\hline RGDP & -0.07464 & 0.9620 & 0.9653 & 0.8185 & 1 \\
\hline
\end{tabular}

From the above table:

- CAPEXP has a positive but weak correlation with FEDRETREV, RECEXP and NON-OIL REV respectively, but a negative and weak correlation with RGDP

- $\quad$ FEDRETREV has a weak but positive correlation with CAPEXP, but a very strong and positive correlation with NON-OIL REV, RECEXP and RGDP, respectively.

- $\quad$ NON-OIL REVENUE has a weak but positive correlation with CAPEXP, but a very strong and positive correlation with FEDRETREV, RECEXP and RGDP, respectively. 
Ayoka Cynthia Odinakachi, Nzotta Samuel Mbadike and Kanu Success Ikechi

The Effect of Federal Government Revenue and Expenditure On Economic Growth in Nigeria - An

Empirical Review

- $\quad$ RECEXP maintained a positive but poor correlation with CAPEXP. However, it has a very strong and positive correlation with FEDRETREV, NON-OIL REVENUE and RGDP, respectively.

- RGDP has a weak and negative correlation with CAPEXP, but a strong and positive correlation with FEDRETREV, NON-OIL REVENUE and RECEXP, respectively.

\subsubsection{Unit root test}

This was carried out using the Augmented Dickey-Fuller. The summary is shown in table 4.2.1 below:

\begin{tabular}{|l|l|l|l|l|l|}
\hline Variable & $\begin{array}{l}\text { ADF Stat. } \\
\text { (Level) }\end{array}$ & $\begin{array}{l}5 \% \text { Critical } \\
\text { value }\end{array}$ & $\begin{array}{l}\text { ADF } \\
\text { Stat(1 } 1^{\text {ST } D I F F) ~}\end{array}$ & $5 \%$ Critical value & Remark \\
\hline RGDP & -0.078277 & -2.960411 & $-4.895840^{*}$ & -2.960411 & $\mathrm{I}(1)$ \\
\hline CAPEXP & $-4.070157^{*}$ & -2.951125 & -6.383951 & -2.950421 & $\mathrm{I}(0)$ \\
\hline RECEXP & -0.598226 & -3.632900 & $-5.319471^{*}$ & -2.951125 & $\mathrm{I}(1)$ \\
\hline NON-OIL REV & 2.236721 & -2.948404 & $-4.750310^{*}$ & -3.639407 & $\mathrm{I}(1)$ \\
\hline FEDRETREV & -0.324319 & -2.951125 & $-6.549778^{*}$ & -2.951125 & $\mathrm{I}(1)$ \\
\hline
\end{tabular}

Source: Researcher's compilation from E-views 10 Regression output.

From the above test CAPEXP achieved stationarity at level while, NON-OIL REV, RECEXP, FEDRETREV and RGDP turned stationary at first difference.

\subsubsection{ARDL BOUNDS TEST FOR COINTEGRATION}

F-Bounds Test

Null Hypothesis: No level relationship

\begin{tabular}{lcccc}
\hline \hline Test Statistic & Value & Signif. & $\mathrm{I}(0)$ & $\mathrm{I}(1)$ \\
\hline \hline F-statistic & $5.76515010 \%$ & 2.2 & 3.09 \\
$\mathrm{k}$ & 4 & $5 \%$ & 2.56 & 3.49 \\
& & $2.5 \%$ & 2.88 & 3.87 \\
& & $1 \%$ & 3.29 & 4.37 \\
\hline \hline
\end{tabular}

Decision: The table above shows that there exists presence of long run relationship in the model since the F-statistic has a value greater than the $\mathrm{I}(0)$ and $\mathrm{I}(1)$ bounds respectively at $5 \%$ level of significance.

\section{Table 4.3.1: ARDL Estimation}

Dependent Variable: RGDP

Method: ARDL

Selected Model: $\operatorname{ARDL}(4,1,2,1,1)$

\begin{tabular}{lllll}
\hline \hline Variable & Coefficient & Std. Error & t-Statistic & Prob.* \\
\hline \hline RGDP(-1) & 0.611927 & 0.278172 & 2.199814 & 0.0465 \\
RGDP(-2) & -0.355929 & 0.328706 & -1.082819 & 0.2986 \\
RGDP(-3) & 0.529324 & 0.331759 & 1.595510 & 0.1346 \\
RGDP(-4) & -0.518058 & 0.269861 & -1.919721 & 0.0771 \\
RECEXP & -5.787987 & 3.715925 & -1.557617 & 0.1433 \\
RECEXP(-1) & 5.954637 & 2.893734 & 2.057769 & 0.0602 \\
CAPEXP & 3.521871 & 3.076080 & 1.144922 & 0.2729 \\
CAPEXP(-1) & -9.018546 & 3.273383 & -2.755115 & 0.0164 \\
CAPEXP(-2) & 5.941335 & 4.068535 & 1.460313 & 0.1679 \\
NON-OILREV & -3.443953 & 2.684507 & -1.282900 & 0.2219 \\
NON-OILREV(-1) & 3.482940 & 2.371720 & 1.468529 & 0.1657 \\
FEDRETREV & 2.473763 & 1.940494 & 1.274811 & 0.2247 \\
FEDRETREV(-1) & 6.285491 & 1.980960 & 3.172952 & 0.0073 \\
C & 13152.77 & 6490.332 & 2.026517 & 0.0637 \\
\hline \hline
\end{tabular}


Ayoka Cynthia Odinakachi, Nzotta Samuel Mbadike and Kanu Success Ikechi

The Effect of Federal Government Revenue and Expenditure On Economic Growth in Nigeria - An

Empirical Review

\begin{tabular}{llll} 
R-squared & 0.996639 & Mean dependent var & 31889.01 \\
Adjusted R-squared & 0.993278 & S.D. dependent var & 15544.00 \\
S.E. of regression & 1274.433 & Akaike info criterion & 17.44454 \\
Sum squared resid & 21114342 & Schwarz criterion & 18.11646 \\
Log likelihood & -221.5013 & Hannan-Quinn criter. & 17.64434 \\
F-statistic & 296.5234 & Durbin-Watson stat & 1.943525 \\
Prob(F-statistic) & 0.000000 & & \\
\hline \hline
\end{tabular}

From the table above, CAPEXP was found to have a positive relationship with RGDP at the current and $2^{\text {nd }}$ time lag but showed a negative relationship with RGDP at the $1^{\text {st }}$ time lag respectively. However.it was only significant at the $1^{\text {st }}$ time lag.

Examining the relationship between RECEXP and RGDP; it was found that at the current period, it had a negative relationship, but a positive one at the $1^{\text {st }}$ time lag. However, it was neither significant at any of these time periods.

NON-OIL REV showed a negative relationship with RGDP at the current period, but a positive one at the $1^{\text {st }}$ time lag. However, it was neither significant at any of these time periods.

FEDRETREV showed a positive relationship with RGDP in the current and $1^{\text {st }}$ time lag period, although only significant at $1^{\text {st }}$ lag.

\section{Table 4.3.2: ARDL Dynamic Short Run Error Correction Model}

Dependent Variable: D(RGDP)

Selected Model: ARDL(4, 1, 2, 1, 1)

Case 2: Restricted Constant and No Trend

Date: 05/20/20 Time: 07:37

Sample: 1983 2018; Included observations: 27

ECM Regression

Case 2: Restricted Constant and No Trend

\begin{tabular}{lllll}
\hline \hline Variable & Coefficient & Std. Error & t-Statistic & Prob. \\
\hline \hline D(RGDP(-1)) & 0.344663 & 0.151930 & 2.268569 & 0.0410 \\
$D($ RGDP(-2)) & -0.011267 & 0.118426 & -0.095138 & 0.9257 \\
$D($ RGDP(-3)) & 0.518058 & 0.157935 & 3.280195 & 0.0060 \\
$D($ RECEXP) & -5.787987 & 2.304426 & -2.511682 & 0.0260 \\
$D($ CAPEXP) & 3.521871 & 2.276274 & 1.547209 & 0.1458 \\
$D($ CAPEXP(-1)) & -5.941335 & 2.181997 & -2.722889 & 0.0174 \\
$D($ NON-OILREV $)$ & -3.443953 & 1.552823 & -2.217866 & 0.0450 \\
D(FEDRETREV) & 2.473763 & 0.982807 & 2.517039 & 0.0257 \\
CointEq(-1)* & -0.732735 & 0.105877 & -6.920628 & 0.0000 \\
\hline \hline R-squared & 0.813341 & Mean dependent var & 1735.702 \\
Adjusted R-squared & 0.730381 & S.D. dependent var & 2085.823 \\
S.E. of regression & 1083.060 & Akaike info criterion & 17.07417 \\
Sum squared resid & 21114342 & Schwarz criterion & 17.50612 \\
Log likelihood & -221.5013 & Hannan-Quinn criter. & 17.20261 \\
Durbin-Watson stat & 1.943525 & & & \\
\hline \hline
\end{tabular}

\section{Short Run Analysis:}

From the short run Error correction model above, CAPEXP has a positive coefficient and relationship in with RGDP in the current period, but a negative coefficient in the $1^{\text {st }}$ time lag. However, it was only significant at the $1^{\text {st }}$ time lag RECEXP was found to have a negative coefficient and relationship and showed to be also significant at $5 \%$ level of significance.

NON-OIL REV was found to have a negative coefficient and relationship in with RGDP. It also showed a significant relationship with RGDP at 5\% level of significance. 
Ayoka Cynthia Odinakachi, Nzotta Samuel Mbadike and Kanu Success Ikechi

The Effect of Federal Government Revenue and Expenditure On Economic Growth in Nigeria - An

Empirical Review

FEDRETREV was also found to have a positive coefficient and relationship with RGDP. It also showed a significant relationship with RGDP at 5\% level of significance.

The Error correction coefficient was negative as expected and significant at 5\% level of significance; hence, satisfied the conditions for error correction. This means that the disequilibrium found in the short run will be adjusted in the long run at a very high speed of 73 $\%$ annually.

Table 4.3.3: ARDL Long Run Form Long Run Form

Dependent Variable: D(RGDP)

Selected Model: ARDL(4, 1, 2, 1, 1)

Case 2: Restricted Constant and No Trend

Date: 05/20/20 Time: 07:36

Sample: 1983 2018; Included observations: 27

Conditional Error Correction Regression

\begin{tabular}{lllll}
\hline \hline Variable & Coefficient & Std. Error & t-Statistic & Prob. \\
\hline \hline C & 13152.77 & 6490.332 & 2.026517 & 0.0637 \\
RGDP(-1)* & -0.732735 & 0.366964 & -1.996747 & 0.0672 \\
REC_EXP(-1) & 0.166651 & 2.979039 & 0.055941 & 0.9562 \\
CAPEXP(-1) & 0.444660 & 3.288323 & 0.135224 & 0.8945 \\
NON-OILREV(-1) & 0.038987 & 2.581387 & 0.015103 & 0.9882 \\
FEDRETREV(-1) & 8.759254 & 3.434923 & 2.550058 & 0.0242 \\
D(RGDP(-1)) & 0.344663 & 0.299151 & 1.152134 & 0.2700 \\
D(RGDP(-2)) & -0.011267 & 0.310012 & -0.036343 & 0.9716 \\
D(RGDP(-3)) & 0.518058 & 0.269861 & 1.919721 & 0.0771 \\
D(REC_EXP) & -5.787987 & 3.715925 & -1.557617 & 0.1433 \\
D(CAPEXP) & 3.521871 & 3.076080 & 1.144922 & 0.2729 \\
D(CAPEXP(-1)) & -5.941335 & 4.068535 & -1.460313 & 0.1679 \\
D(NON-OILREV) & -3.443953 & 2.684507 & -1.282900 & 0.2219 \\
D(FEDRETREV) & 2.473763 & 1.940494 & 1.274811 & 0.2247 \\
\hline \hline
\end{tabular}

* p-value incompatible with t-Bounds distribution.

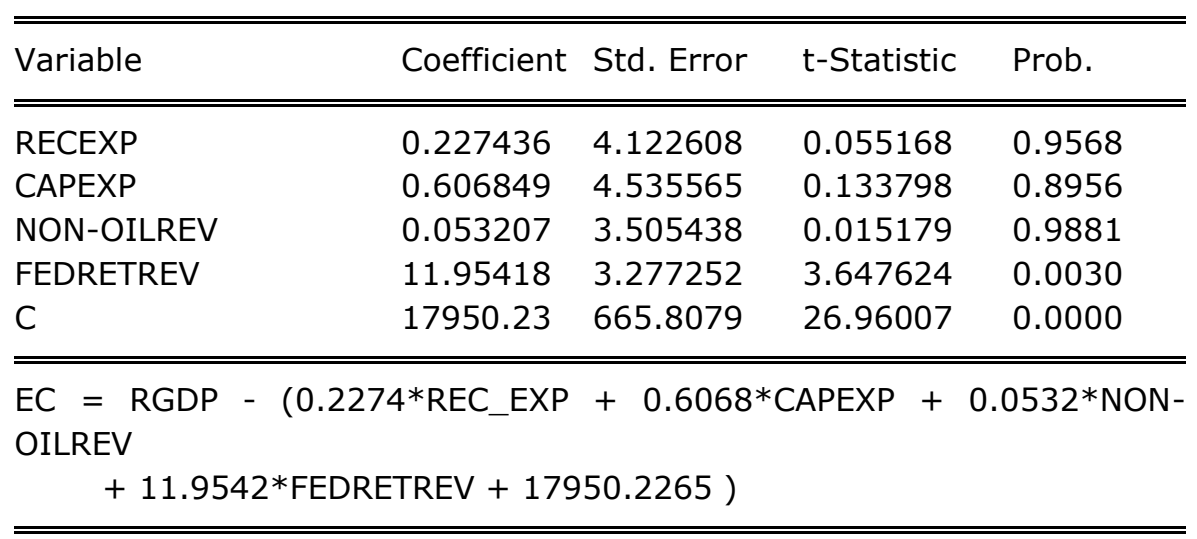

\section{Long run analysis}

From the long run form of ARDL model, the coefficients of :Constant (C), RECEXP , CAPEXP , NON-OIL REV and FEDRET REV, all had a positive relationship with RGDP. This shows that when other explanatory variables are held constant, RGDP will increase by $17950.23,0.227436$, $0.606849,0.053207$ and 11.95418 units respectively.

Table 4.3.4: A review of our apriori expectations

\begin{tabular}{|l|l|l|l|l|}
\hline Variable & Definition & $\begin{array}{l}\text { Expected } \\
\text { sign }\end{array}$ & $\begin{array}{l}\text { Obtained } \\
\text { sign }\end{array}$ & Remarks \\
\hline
\end{tabular}


Ayoka Cynthia Odinakachi, Nzotta Samuel Mbadike and Kanu Success Ikechi

The Effect of Federal Government Revenue and Expenditure On Economic Growth in Nigeria - An

Empirical Review

\begin{tabular}{|l|l|l|l|l|}
\hline NON-OIL REV & Non-oil revenue & $(+)$ & $(-)$ & $\begin{array}{l}\text { Does not } \\
\text { Conform }\end{array}$ \\
\hline CAPEXP & Capital expenditure & $(+)$ & $(+)$ & Conform \\
\hline RECEXP & Recurrent expenditure & $(+)$ & $(-)$ & $\begin{array}{l}\text { Does not } \\
\text { Conform }\end{array}$ \\
\hline FEDRETREV & $\begin{array}{l}\text { Fed.. government retained } \\
\text { revenue }\end{array}$ & $(+)$ & $(+)$ & Conforms \\
\hline
\end{tabular}

Source: Researcher's compilation (2019)

\subsection{Test of Hypotheses.}

i) $H_{0}$ : NON-OIL REV has no significant relationship with economic growth in Nigeria at $a=0.05$ Decision rule: Since the prob.value $(0.0450)<0.05$ the null hypothesis is rejected. Thus, we conclude that non-oil revenue has no significant relationship with economic growth in Nigeria

ii. Ho: FEDRETREV has no significant relationship with economic growth in Nigeria at $a=0.05$

Decision: Since the prob.value $(0.0257)<0.05$ the null hypothesis is rejected. Thus, we conclude that federal government retained revenue has a significant relationship with economic growth in Nigeria.

iii. Ho: RECEXP has no significant relationship with economic growth in Nigeria at $a=0.05$

Decision: Since the prob.value $(0.0260)<0.05$ the null hypothesis is rejected. Thus, we conclude that recurrent expenditure has a significant relationship with economic growth in Nigeria..

iv. Ho: CAPEXP has no significant relationship with economic growth in Nigeria at $a=0.05$ Decision: Since the prob. value $(0.1458)>0.05$ the null hypothesis is accepted. Thus we concluded that capital expenditure has no significant relationship with economic growth in Nigeria

\subsubsection{Joint Test of Significance (ANOVA)}

Decision: From table 4.3.1 above, the F-prob. value is 0.000000 which is less than 0.05 ; hence we reject the null hypothesis and conclude that there is a joint impact of all the explanatory variables (RECEXP, CAPEXP, NON-OIL REV and FEDRETREV) on RGDP at 5\% level of significance.

\subsubsection{Granger Causality Test}

\begin{tabular}{|c|c|c|c|}
\hline Null Hypothesis: & Obs & F-Statistic & Prob. \\
\hline FEDRETREV does not Granger Cause CAPEXP & 34 & 1.59075 & 0.2210 \\
\hline CAPEXP does not Granger Cause FEDRETREV & & 6.69229 & 0.0041 \\
\hline NON_OIL_REV does not Granger Cause CAPEXP & 34 & 0.39727 & 0.6758 \\
\hline CAPEXP does not Granger Cause NON-OILREV & & 2.70893 & 0.0834 \\
\hline RECEXP does not Granger Cause CAPEXP & 34 & 5.53726 & 0.0092 \\
\hline CAPEXP does not Granger Cause RECEXP & & 1.56374 & 0.2265 \\
\hline RGDP does not Granger Cause CAPEXP & 31 & 11.2314 & 0.0003 \\
\hline CAPEXP does not Granger Cause RGDP & & 9.72411 & 0.0007 \\
\hline NON-OILREV does not Granger Cause FEDRETREV & 34 & 1.38876 & 0.2655 \\
\hline FEDRETREV does not Granger Cause NON-OILREV & & 1.56243 & 0.2268 \\
\hline RECEXP does not Granger Cause FEDRETREV & 34 & 6.22366 & 0.0056 \\
\hline FEDRETREV does not Granger Cause RECEXP & & 1.14263 & 0.3329 \\
\hline RGDP does not Granger Cause FEDRETREV & 31 & 1.49789 & 0.2423 \\
\hline FEDRETREV does not Granger Cause RGDP & & 16.0580 & 3.E-05 \\
\hline
\end{tabular}


Ayoka Cynthia Odinakachi, Nzotta Samuel Mbadike and Kanu Success Ikechi

The Effect of Federal Government Revenue and Expenditure On Economic Growth in Nigeria - An Empirical Review

\begin{tabular}{|c|c|c|c|}
\hline $\begin{array}{l}\text { RECEXP does not Granger Cause NON-OILREV } \\
\text { NON-OILREV does not Granger Cause RECEXP }\end{array}$ & 34 & $\begin{array}{l}5.74895 \\
2.69940\end{array}$ & $\begin{array}{l}0.0079 \\
0.0841\end{array}$ \\
\hline RGDP does not Granger Cause NON-OILREV & 31 & 2.81662 & 0.0781 \\
\hline NON-OILREV does not Granger Cause RGDP & & 1.38674 & 0.2678 \\
\hline RGDP does not Granger Cause RECEXP & 31 & 10.0245 & 0.0006 \\
\hline RECEXP does not Granger Cause RGDP & & 17.1583 & 2.E-05 \\
\hline
\end{tabular}

Source : Extract from E-views 10 output

From the above table, it can be seen that causality exists and flows uni-directionally from CAPEXP to FEDRETREV; CAPEXP to NON-OIL REV; RECEXP to CAPEXP; RECEXP to FEDRETREV; RGDP to FEDRETREV; FEDRETREV to RGDP and RECEXP to NON-OIL REV.

Also, bi-directional causality exists and flows from RGDP to CAPEXP and RGDP to RECEXP and vice-versa respectively as their probability values were all less than 0.05 level of significance..

\subsection{Post Estimation Test.}

i. Breusch -Godfrey test for Serial Autocorrelation.

$\mathbf{H}_{\mathbf{0}}$ : There is no serial autocorrelation in the model.

$\mathbf{H}_{\mathbf{1}}$ : There is presence of serial autocorrelation in the model.

Breusch-Godfrey Serial Correlation LM Test:

\begin{tabular}{llll}
\hline \hline F-statistic & 0.497427 & Prob. F(2,11) & 0.6211 \\
Obs*R-squared & 2.239383 & Prob. Chi-Square(2) & 0.3264 \\
\hline \hline
\end{tabular}

From the Regression output, Prob.chi-square $(2)=0.3264$

Decision: Since Prob.chi-square is greater than 0.05, it means that there is no serial autocorrelation in the model.

\section{ii. Heteroscedasticity Test .}

$\mathbf{H}_{\mathbf{0}}$ : There is no heteroscedasticity in the model.

$\mathbf{H}_{\mathbf{1}}$ : There is presence of heteroscedasticity in the model.

Heteroskedasticity Test: Breusch-Pagan-Godfrey

\begin{tabular}{llll}
\hline \hline F-statistic & 1.183803 & Prob. F(13,13) & 0.3828 \\
Obs*R-squared & 14.63625 & Prob. Chi-Square(13) & 0.3306 \\
Scaled explained SS & 4.092911 & Prob. Chi-Square(13) & 0.9902 \\
\hline \hline
\end{tabular}

From the Regression output, Prob.chi-square $(17)=0.3306$

Decision: Since Prob. Chi-square is greater than 0.05 , it means that there is no heteroscedasticity in the model.

\subsubsection{Goodness of Fit of The Model. Adj. $\mathbf{R}^{2}=\mathbf{0 . 7 3 0 3 8 1 \times 1 0 0 \% = 7 3 \%}$}

From the result of the regression, the Adjusted R-squared shows that about $73 \%$ variation in economic growth can be explained by the revenue and expenditure variables. This means the model has a very strong explanatory power in relation to economic growth in Nigeria.

\section{Fig 1: Stability of the model via CUSUM}


Ayoka Cynthia Odinakachi, Nzotta Samuel Mbadike and Kanu Success Ikechi

The Effect of Federal Government Revenue and Expenditure On Economic Growth in Nigeria - An

Empirical Review

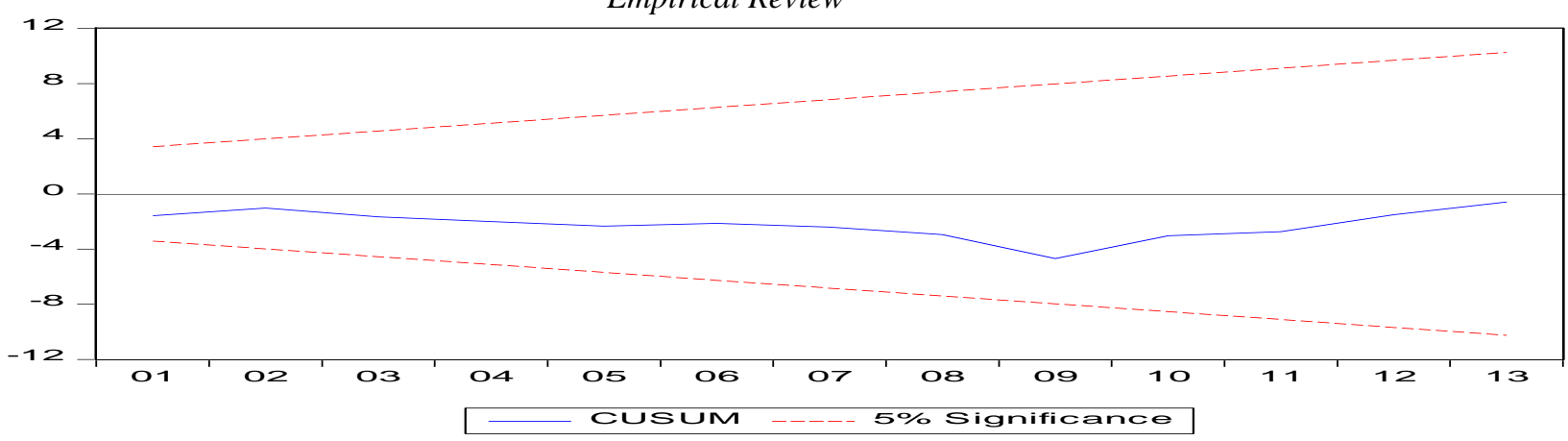

From the result above, the CUSUM line lies within the $5 \%$ bands; hence the model is stable at $5 \%$ level of significance.

\subsection{3: Fig 2: Stability of the model via CUSUM of squares}

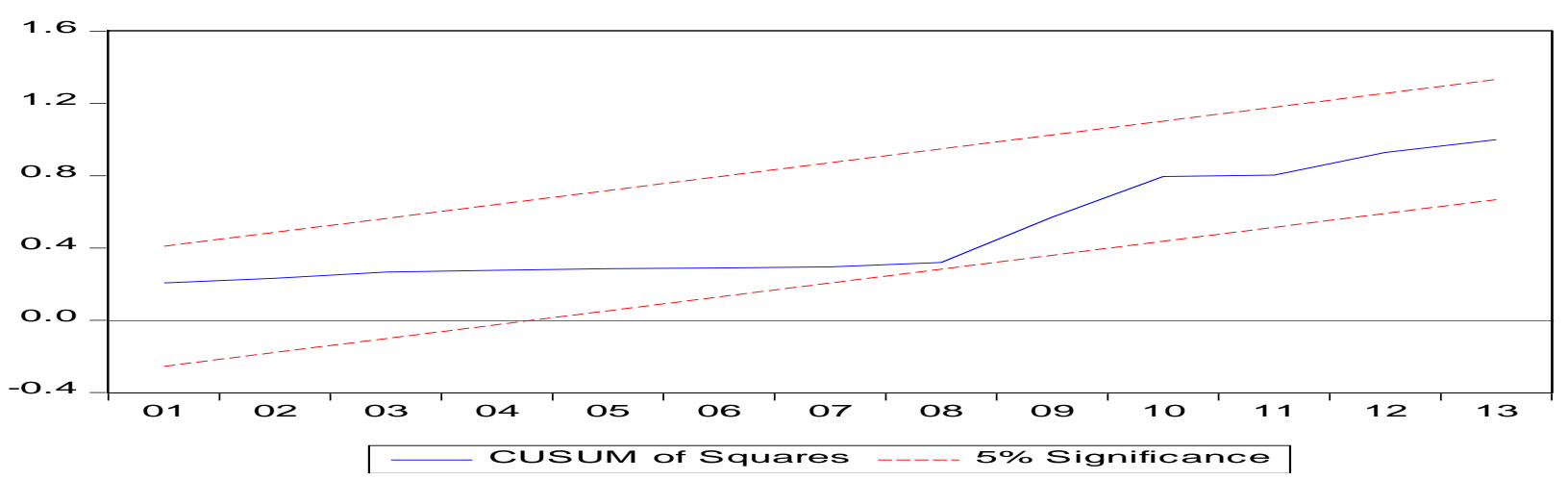

From the figure above, the CUSUM of squares line lies within the $5 \%$ bands; hence the model is stable at $5 \%$ level of significance.

\subsubsection{Forecast of Analysis}

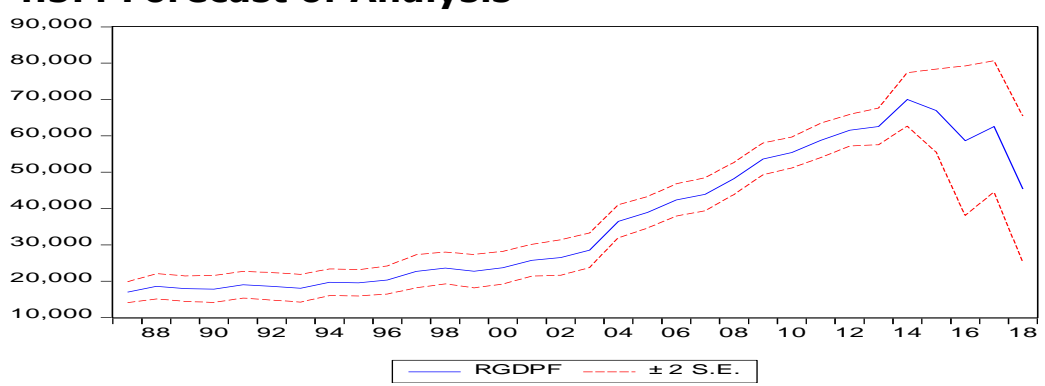

\begin{tabular}{|c|c|}
\hline \multicolumn{2}{|l|}{ Forecast: RGDPF } \\
\hline \multicolumn{2}{|l|}{ Actual: RGDP } \\
\hline \multicolumn{2}{|l|}{ Forecast sample: 19832018} \\
\hline \multicolumn{2}{|l|}{$\begin{array}{l}\text { Adjusted sample: } 19872018 \\
\text { Included observations: } 32\end{array}$} \\
\hline Root Mean Squared Error & 5663.91 \\
\hline Mean Absolute Error & 2497.012 \\
\hline Mean Abs. Percent Error & 5.627120 \\
\hline Theil Inequality Coefficient & 0.069859 \\
\hline Bias Proportion & 0.087443 \\
\hline Variance Proportion & 0.189894 \\
\hline Covariance Proportion & 0.722664 \\
\hline Theil U2 Coefficient & 1.107246 \\
\hline Symmetric MAPE & 5.967552 \\
\hline
\end{tabular}

From the above figure, the forecasts are not biased. The bias proportion is very minimal i.e., 0.0087443 and has a very small variance proportion of 0.189894 . This means that most of the forecast errors are rightly attributable to the covariance proportion component which is 0.722664 .i.e., $72 \%$.The Theil inequality coefficient is a measure of the accuracy of a set of predictions generated from some sample model and is shown above to be 0.069859.i.e, 6.9\% and it is closer to zero; hence, shows that the time series are not significantly different from another. The Mean absolute percentage error is far less than $100 \%$ i.e., $5.63 \%$; hence validating the forecast.

\subsection{Discussion and Findings.}

The outcomes of study are briefly reviewed below:

i) FEDRETREV: The coefficient is 2.473763and conforms to our a priori expectation. This suggests that federal government retained revenue has a positive effect on economic growth of Nigeria as it was statistically significant at $5 \%$ level of significance. This means that government retained revenue can be used as a veritable instrument to increase the rate of economic growth in Nigeria. This supports the Keynesian view that government involvement is necessary to 
Ayoka Cynthia Odinakachi, Nzotta Samuel Mbadike and Kanu Success Ikechi

The Effect of Federal Government Revenue and Expenditure On Economic Growth in Nigeria - An

Empirical Review

augment the workings of the invisible hand, and this is achievable through fiscal synchronization.

ii) NON-OIL REV: The coefficient of non-oil revenue is -3.443953and has a negative relationship with economic growth in Nigeria. The sign does not conform to our a priori expectation with a high magnitude. This negative relationship can be attributable to the priority shift from non-oil sector to the oil sector due to the emergence of oil.

iii) RECEXP: The coefficient of recurrent expenditure is -5.787987and has a negative relationship with the economic growth of Nigeria. This result was in tandem with the earlier works of Ohwofasa, Obeh, and Atumah (2012) and Chude and Chude (2013).

iii. CAPEXP: The coefficient of capital expenditure is 3.521871and has a positive relationship with economic growth of Nigeria. Expenditure on capital expenditure if well managed could give rise to rapid economic growth

\section{Conclusion and Recommendations}

\subsection{Summary}

Outcome of study revealed that non-oil revenue, recurrent expenditure and retained revenue were statistically significant at $5 \%$ level of significance, while capital expenditure was insignificant. However, the explanatory variables were jointly significant at $5 \%$ level of significance.

\subsection{Conclusion}

The study showed that federal government retained revenue, non-oil revenue and recurrent expenditure among the independent variables were all statistically significant at $5 \%$ level of significance in the short run..In the long run FEDRETREV also turned out to be statistically significant.

\subsection{Recommendations}

This study made the following recommendations:

i. Federal government retained revenue should be maintained as a veritable instrument for fiscal adjustments. Non-oil revenue should be sourced to transform the Nigerian economy and complement oil revenue. The country should seek revenue from her solid minerals and agriculture to shore up her foreign earnings and utilize such to achieve economic growth in the short run and long run.

ii. Recurrent expenditures should be minimized to the barest minimum as this has eroded capital formation The cost of administration at the federal and state level should be reduced or matched by internally generated revenue. By keeping a ceiling on recurrent expenditure, the economy can achieve greater savings for investment purpose that would bring about rising output and economic growth; and lastly.

iii. The capital expenditure of the country should cautiously be raised, as not all capital expenditure produce positive results. Government should show more interest in human capital and research and development as this could transfer its positive externality effect to the growth of Nigerian economy in the long run.

\subsection{Suggestion for Further Studies.}

This study is only a perspective of the researcher's interest on the topic and not a totality in itself; the following are suggested:

i. In subsequent studies, researchers should consider ratios such as size of government and growth rates where possible.

ii. The sample size should be reviewed to see if more robust results can be obtained; hence a study, say from1990- date might suffice.

A VAR analysis will be adequate to capture the interaction between the variables when they are all transformed exogenously to become endogenous at some point. This will show greater interaction among the variables and their causality effects. 
Ayoka Cynthia Odinakachi, Nzotta Samuel Mbadike and Kanu Success Ikechi

The Effect of Federal Government Revenue and Expenditure On Economic Growth in Nigeria - An

Empirical Review

\section{References}

- Abu, N. and Abdulahi, U. (2010). "Government Expenditure and Economic Growth in Nigeria, 1970-2008: A Disaggregated Analysis", Business and Economic Journal, 4(3): 237-330. Available at: http://astoujournals/com.

- Aigbokhan, B.E. (1996). "Government Size and Economic Growth: The Nigerian Experience", in "Beyond Adjustment: Management of the Nigerian Economy". Proceedings of the 1996 annual Conference of the Nigerian Economic Society.

- Aigheyisi,O. S. (2010). Examining the Relative Effectiveness of Monetary and Fiscal Policies in Nigeria: A Cointegration and Error Correction Approach,2010.[Online]. Available at SSRN: http://ssrn.com/abstract=1944585 or http:// dx. doi. Org / 10.2139/ssrn.1944585 [13 May 2013].

- Akpan, N.I. (2005). "Government Expenditure and Economic Growth in Nigeria, A Disaggregated Approach", Central Bank of Nigeria Financial Review, Vol. 43, No.1, p. 21.

- Akpokerere, O. E.\&Ighoroje, E. J. (2013). The effect of government expenditure on economic growth in Nigeria: A disaggregated analysis from 1977 to 2009. International journal of conomic development research and investment, 4(1).

- Anyafo, A.M.O. (1996), Public Finance in Developing Economy: The Nigerian Case, UNEC Publications, Enugu.

- Aregbayan, O. \&Akpan, F. (2013). Long-term determinant of government expenditure: A disaggregate analysis of Nigeria. Journal of studies in social sciences,5(1)

- Central Bank of Nigeria. Statistical Bulletin(2011-2015)

- Aregbeyen, O. (2006). "Cointegration, Causality and Wagner's Law: A Test for Nigeria, 1970-2003", Central Bank of Nigeria Economic and Financial Review, Vol. 44, No. 2.

- Arpaia, A. and A. Turrini (2008), Government expenditure and economic growth in the EU: long-run tendencies and short-term adjustment, Economic Papers 300, European Economy, Economic and Monetary Union, February.

- Babatunde, M.A. and R.A. Adefabi (2005). "Long Run Relationship between Education and Economic Growth in Nigeria: Evidence from the Johansen's Cointegration Approach". Paper presented at the Regional Conference on Education in West Africa: Constraints and Opportunities Dakar, Senegal, November 1-2. Cornell University / CREA / Ministèrede I'Education du Sénégal.

- Baghestani, H. and R. McNown (1994). "Revenues or Expenditures Respond to Budgetary Disequilibria?" Southern Economic Journal, Vol. 61, No. 2, p. 14. Public and Municipal Finance, Volume 1, Issue 2, 201235

- Barro, R. J. (1990). "Government Spending in a Simple Model of Endogeneous Growth", The Journal of Political Economy, 98(5): 103-125.

- Barro, R., and Martin, I. (1992). "Public Finance in Models of Economic Growth" Review of Economic Studies, 59(3): 645-661. Bhatia, H.L. (2008). Public Finance (26th ed.). Vikas Publishing House PVT Ltd, New Delhi.

- Barro, R.J. (1979). "On the Determination of Public Debt", Journal of Political Economy, October, pp. 940-971.

- Barro, R.J. and X. Sala-i-Martin (1992). "Public Finance in Models of Economic Growth", Review of Economic Studies, 59, pp. 645-661.

- Bhatia, H.L. (2008). Public Finance (26th ed.). Vikas Publishing House PVT Ltd, New Delhi.

- Bhatia, H.L., 2009. Public Finance. 25th Edn., Vikas Oshadami, O.L., 2006. The impact of domestic debt on Publishing House, India,

- Blackley, P. (1986). "Causality Between Revenues and Expenditures and the Size of the Federal Budget", Public Finance Quarterly, April, pp. 139-156.

- CBN Economic anf Financial Review, Vol. 26 (2), June, pp. 46-61.

- Central Bank of Nigeria (2008). 50 Years Anniversary Statistical Bulleting. CBN, Abuja. 
Ayoka Cynthia Odinakachi, Nzotta Samuel Mbadike and Kanu Success Ikechi

The Effect of Federal Government Revenue and Expenditure On Economic Growth in Nigeria - An

Empirical Review

- Central Bank of Nigeria (2011). Statistical Bulletin Central Bank of Nigeria. 1(1), December.

- Central Bank of Nigeria (2015). Statistical Bulletin Central Bank of Nigeria. 1(1), December

- $\quad$ Chang, T., W.R. Liu, and S.B. Caudill (2002). "Tax-and-spend, spend-and-tax, or fiscal synchronization: New evidence for ten countries", Applied Economics, 34, pp. 15531561.

- Chude, N. P, \&Chude, D. I. (2013). Impact of government expenditure on economic growth in Nigeria. International journal of business and management review,1(4), 6471. Ebong, F.,Ogwunike,

- $\quad$ Dalton, H. (1954). Principles of Public Finance. pp 145.

- Ebong, F.,Ogwunike, F.,Udongwo, U. \&Ayodele O.(2016).Impact of government expenditure on economic growth in Nigeria: A disaggregated analysis. Asian journal of economics and empirical research 3(1), 113-121.

- Eita, J.H. and D. Mbazima (2008). "The Causal Relationship Between Government Revenue and Expenditure in Namibia", MPRA Paper No. 9154.

- Emori, E. G. Duke, S. B. \&Nneji, I. D.(2015).Impact of public expenditure on economic growth in Nigeria.International Journal of scientific research and management (IJSRM) 3(2) 3694-3700.

- Engle, R.F. \& Granger, C.W.J. (1987). Co-integration and error correction: representation, estimation, and testing. Econometrica 55, 251-276.

- Essien E.A. (1997). "Public Sector Growth, An Econometric Test of Wagner's Law", Economic and Financial Review, Vol. 35, No. 3, p. 23.

- Fajingbesi, A. A. and Odusola, A. F. (1999): "Public Expenditure and Growth". A Paper Presented at a Training Programme on Fiscal Policy Planning Management in Fatas, A., J. von

- Fajingbesi, O. and B. Odusola (1999). "Public expenditure and growth". A paper presented at a training programme on Fiscal Policy Planning and Management in Nigeria, organized by NCEMA, Ibadan, pp. 137-179.

- $\quad$ IMF (2012). International Monetary Fund. www.imf.org.

- Jain, T.R., S.J. Kaur, A. Gupta, and S.P. Gupta (2008). International trade and Public Finance. VK Publications.

- Jhinghan, M. L. (2011). The economics of development and planning. Delhi: Vrinda publications Itd.

- Jones, J.D., and D. Joulfaian (1991). "Federal Government Expenditures and Revenues in the Early Years of the American Republic: Evidence from 1972 to 1860", Journal of Macroeconomics, Winter, pp. 133-155.

- Joulfaian, D. and R. Mookerjee (1991). Dynamics of government revenues and expenditures in industrial economies, Applied Economics, 23, pp. 1839-1844.

- Keynes JM (1936). The General Theory of Employment, Interest and Money, Vol. 7, Cambridge: MacMillan.

- Keynes, J.M. (1936). "General Theory of Employment, Interest and Money", London: Macmillan.

- Koren, S., and A. Stiassny (1998). "Tax and spend, or spend and tax? An international study", Journal of Policy Modeling, 20, pp. 163-191.

- $\quad$ Lipsey, R. \& Chrystal, K. (2007). Economics.Oxford: Oxford University Press. Nworji, I. D, Okwu, A. T,

- Maku, O.E. (2009). "Does Government Spending Spur Economic Growth in Nigeria? Munich Personal RePEc Archive. Retrieved on 13/8/2010 from http://mpra.ub.unimuenchen.de/17941/ MPRA Paper no. 17941. NG- Journal of Social Development (NGJSD) • ISSN: 0189-5958 48

- Muritala, T. and Taiwo, A. (2011).Government expenditure and economic development: Empirical evidence from Nigeria. European Journal of Business and Management, 3 (9), 2011. 
Ayoka Cynthia Odinakachi, Nzotta Samuel Mbadike and Kanu Success Ikechi

The Effect of Federal Government Revenue and Expenditure On Economic Growth in Nigeria - An

Empirical Review

- Musgrave, R.A. (1969). Fiscal Systems, London: Yale University Press Musgrave, R.A. and Musgrave, B. (1988), Public Finance in Theory and Practice, New York: McGraw-Hill Book Company.

- Obiwuru, T. C., \&Nworji, L. O. (2012).Effects of public expenditure on economic growth in Nigeria: A disaggregated time series analysis. International journal of management sciences and business research,1(7), 2226-8235. Ogba, L. (1999). Element of public finance. 2 nd edition Heritage publication.

- Odedokun, M.O. (1997). "Relative effects of public versus private investment spending on economic efficiency in developing countries". Journal of Applied Economics

- Ogboru, I. (2006). Readings in economic development and planning. Ilorin: University of Ilorin press

- Ogundipe, A. A. \&Oluwatobi,S. (2010). Government spending and economic growth in Nigeria: evidence from disaggregated analysis. Covenant university, www.covenantuniversity.edu.ng.

- Ohwofasa, B. O. Obeh, H. O.\&Atumah, M. (2012). Impact of government expenditure in education on economic growth in Nigeria, 1986-2011: A parsimonious error correction model.African journal of scientific research,10(1).

- Omoruyi, S.E. (1988), the Fluctuation of Federal Government Expenditures: A Statistical Analysis. CBN Economic anf Financial Review, Vol. 26 (2), June, pp. 46-61.

- Owoye, O. (1995). "The causal relationship between taxes and expenditures in the G7 countries: Cointegration and error correction models", Applied Economics Letter, 2, pp. 19-22.

- Oyinlola, M. A., \&Akinnibosun, O. (2013). Public expenditure and economic growth nexus: Further evidence from Nigeria. Journal of economics and international finance, 5(4), 146-154, http://www.academicjournals.org/ JEIF.

- Peacock, A., and J. Wiseman (1979). "Approaches to the Analysis of Government Expenditures Growth", Public Finance Quarterly, January, pp. 3-23.

- Peacock, A. T. \& Wiseman J. A. (1967). The growth of public expenditure in the United Kingdom.Princeton: George Allen union limited.

- Taiwo, M. (2012). Government expenditure and economic development: empirical evidence from Nigeria.European journal of business and management. 3(9).

- Tajudeen, E, \&Fasanya, I. O. (2013). Public expenditure and economic growth in Nigeria: evidence from autoregressive distributed lag specification. Zagreb international review of economics \& business,16(1), 79-92.

- Todaro, M. P. \& Smith, S. C.(2005). Economic development. 9th Edition. Pearson educational limited England.

- Udoffia, D. T.\& Godson, J. R.(2016).The impact of federal government expenditure on economic growth in Nigeria (1981-2014).Greener journal of social sciences 6(4) 92105.

- Wagner, A. (1883). "Three Extracts on Public Finance", translated and reprinted in R.A. Musgrave and A.T. Peacock (eds), Classics in the Theory of Public Finance, London: Macmillan, 1958. 